Prepared in cooperation with the U.S. Environmental Protection Agency and the Sisseton-Wahpeton Sioux Tribe

\title{
Compilation of Data to Support Development of a Pesticide Management Plan by the Sisseton-Wahpeton Sioux Tribe, South and North Dakota
}

Open-File Report 02-381 


\section{Compilation of Data to Support Development of a Pesticide Management Plan by the Sisseton-Wahpeton Sioux Tribe, South and North Dakota}

By Ryan F. Thompson

Open-File Report 02-381

Prepared in cooperation with the

U.S. Environmental Protection Agency and the

Sisseton-Wahpeton Sioux Tribe 


\section{U.S. Department of the Interior}

GALE A. NORTON, Secretary

\section{U.S. Geological Survey}

Charles G. Groat, Director

The use of firm, trade, and brand names in this report is for identification purposes only and does not constitute endorsement by the U.S. Government.

Rapid City, South Dakota: 2002

For additional information write to:

District Chief

U.S. Geological Survey

1608 Mt. View Road

Rapid City, SD 57702

Copies of this report can be purchased from:

\section{U.S. Geological Survey}

Information Services

Building 810

Box 25286, Federal Center

Denver, CO 80225-0286 


\section{CONTENTS}

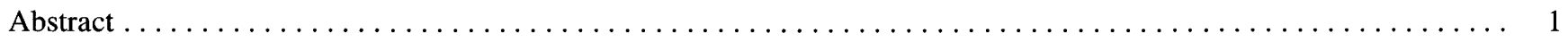

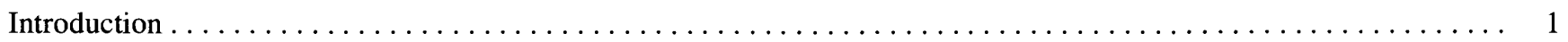

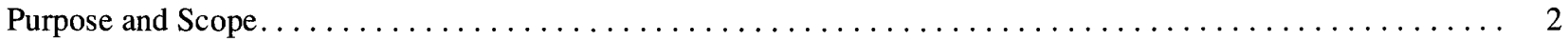

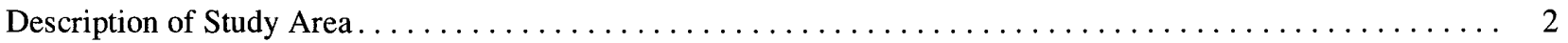

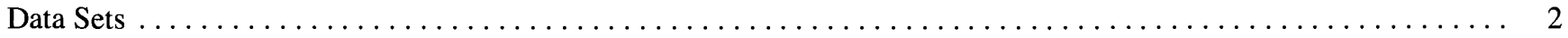

Pesticide Concentrations in Ground Water and Surface Water $\ldots \ldots \ldots \ldots$

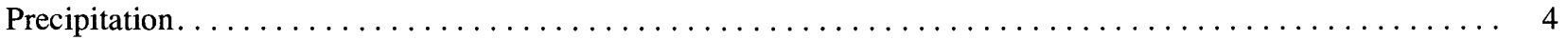

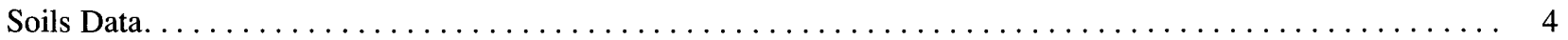

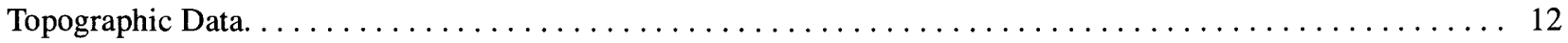

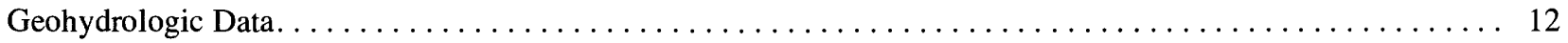

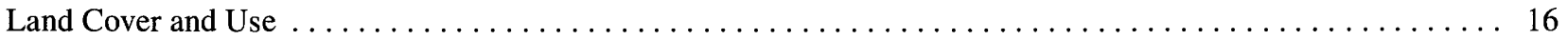

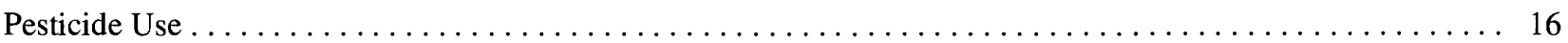

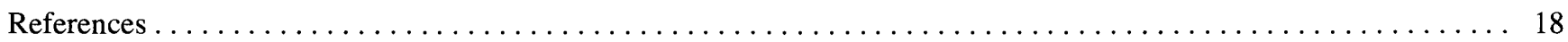

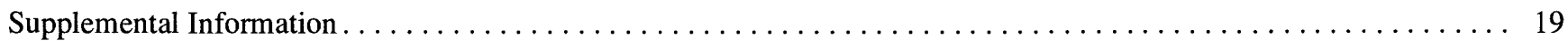

\section{FIGURES}

1. Map showing location of the Lake Traverse Reservation . . . . . . . . . . . . . . . . .

2. Map showing locations of water-quality sampling sites with available pesticide data $\ldots \ldots \ldots$

3. Index map of 7.5 -minute Digital Raster Graphic (DLG) locations. . . . . . . . . . . . . . . . 14

\section{TABLES}

1. Albers Equal Area projection parameters . . . . . . . . . . . . . . . . . . . . . . . . . . . .

2. Summary of pesticide concentrations measured in ground-water samples collected by the South Dakota Geological Survey in the study area $\ldots \ldots \ldots \ldots \ldots \ldots$

3. Pesticide concentrations measured in surface-water samples collected by the South Dakota Geological Survey in the study area $\ldots \ldots \ldots \ldots \ldots \ldots \ldots$

4. Summary of pesticide analyses retrieved from National Water Information System Database

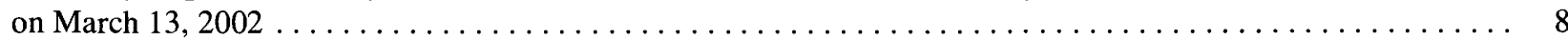

5. Precipitation, in inches, for 2000-01 for seven National Weather Service stations within and

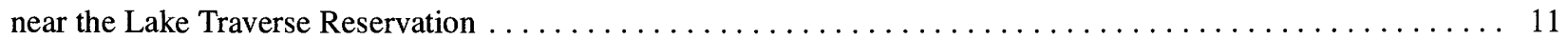

6. Index of Digital Raster Graphics filenames and U.S. Geological Survey 7.5-minute quadrangle map names . . . . 13

7. Summary of geohydrologic data sets for aquifers and outwash in the study area $\ldots \ldots \ldots 15$

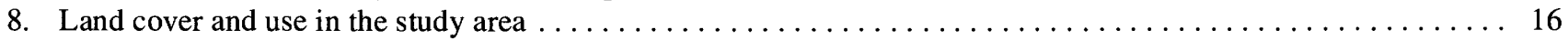

9. Estimated use of 34 herbicides in Roberts County, South Dakota, in $1987 \ldots \ldots$. . . . . . . . . . . . . . . 17 
CONVERSION FACTORS AND VERTICAL DATUM

\begin{tabular}{rccl}
\hline Multiply & By & To obtain \\
\hline acre & 4,047 & square meter \\
acre & 0.4047 & hectare \\
foot & 0.3048 & meter \\
square mile & 259.0 & hectare \\
square mile & 2.590 & square kilometer \\
\hline
\end{tabular}

Vertical coordinate information is referenced to the National Geodetic Vertical Datum of 1929 (NGVD of 1929). 


\title{
Compilation of Data to Support Development of a Pesticide Management Plan by the Sisseton-Wahpeton Sioux Tribe, South and North Dakota
}

\author{
By Ryan F. Thompson
}

\section{ABSTRACT}

The U.S. Environmental Protection Agency is working with the Sisseton-Wahpeton Sioux Tribe to develop a Pesticide Management Plan (PMP) to reduce potential for contamination of ground water that may result from the use of registered pesticides. The purpose of this study was to compile technical information to support development of a PMP by the Sisseton-Wahpeton Sioux Tribe for the area within the 1867 boundary of the Lake Traverse Reservation.

This report provides a compilation of data to support development of a PMP. Available data sets are summarized in the text of this report, and actual data sets are provided in two Compact Disks-Read Only Memory (CD-ROMs) that are included with the report.

The two CD-ROMs contain data sets pertinent to a Pesticide Management Plan. Waterquality analyses for pesticides are summarized for several ground- and surface-water sites. Pesticide concentrations in most samples were found to be below minimum reporting levels. Three geospatial soils coverage databases are included, providing detailed data for the study area where available, and more general data for the entire study area. Topographic data is presented in the form of Digital Raster Graphics and 10-meter Digital Elevation Model coverages. A brief discussion of the ARC/INFO commands used to delineate drainage basins also is given. Geohydrologic data is provided for the 12 aquifers and aquifer systems, five named outwash groups, and for unnamed outwash deposits greater than 5 feet in thickness. A high-resolution (30-by-30 meters) land-cover and use database is provided and summarized in a tabular format. Nearly 77 percent of the study area is used for row crops, pasture, or hay, and over 11 percent of the study area is covered by water or wetlands. Pesticide use for the study area is characterized by four sources at different levels of detail. Within the State, herbicides are commonly applied to corn and soybean crops, which are the primary row crops grown in the study area. This report also describes and summarizes the data sets and files, and how the data is relevant to development of a Pesticide Management Plan.

\section{INTRODUCTION}

Eleven aquifers and numerous named and unnamed outwash bodies are used for domestic, stockwatering, and irrigation purposes within the 1867 boundary of the Lake Traverse Reservation (Thompson, 2001), hereinafter called the Lake Traverse Reservation. Various pesticides (herbicides, insecticides, and fungicides) are applied to cropland, which covers approximately 1,213 square miles, or about 80 percent of the study area. The U.S. Environmental Protection Agency (USEPA) is working with the Sisseton-Wahpeton Sioux Tribe (SWST) to develop 
a Pesticide Management Plan (PMP) to reduce potential for contamination of ground water that may result from the use of registered pesticides. An important component of developing a PMP is to determine specific areas where ground water may be vulnerable to contamination.

The purpose of the study was to compile technical information in support of development of a PMP by the SWST for the Lake Traverse Reservation. This study was performed by the U.S. Geological Survey (USGS) in cooperation with the USEPA and the SWST.

\section{Purpose and Scope}

The purpose of this report is to provide information that can be used by the SWST to develop assessment maps for a PMP for the Lake Traverse Reservation. The report provides a compilation of existing technical data relevant to the PMP process, including water-quality, precipitation, soils, topographic, geohydrologic, land-cover and land-use, and pesticide-use data. The report contains descriptions and summaries of these data sets, and describes how they might be used to evaluate aquifer vulnerability to pesticide contamination. The report also explains the organization of the data sets that are provided on two Compact Disks-Read Only Memory (CD-ROMs) that are included with the report.

\section{Description of Study Area}

The Lake Traverse Reservation encompasses about 1,508 square miles. About 105 square miles of the Reservation are located in southeast North Dakota, with the remainder in northeast South Dakota (fig. 1). In South Dakota, the Reservation includes parts of Marshall, Roberts, Day, Grant, and Codington Counties. In North Dakota, the Reservation includes parts of Richland and Sargent Counties. The Lake Traverse Reservation is located within the Central Lowlands physiographic province. Within the province, the Reservation occupies two physiographic divisions - the Coteau des Prairies and the Minnesota River-Red River Lowlands (fig. 1). The Coteau des Prairies is a plateau of rolling morainal topography formed by the deposition of glacial debris during the Pleistocene Epoch upon a bedrock highland. The Coteau has moderate to high relief, with numerous lakes and wetlands.
Altitudes on the Coteau range from about 1,750 feet near the North Dakota border to 2,135 feet a few miles northwest of the town of Summit, and back to about 1,720 feet near Lake Kampeska (just to the southwest of the southern tip of the Reservation). The western face of the Coteau rises 600 feet above the James River lowland, and the eastern face rises 800 feet above the Minnesota River-Red River Lowlands. The Minnesota River-Red River Lowlands division is a somewhat flat ground moraine that consists of isolated areas of debris left by retreating glaciers. Altitudes in the lowlands range from about 980 feet near the shore of Lake Traverse to about 1,200 feet at the town of Peever, which is near the base of the Coteau. About one-half of the Lake Traverse Reservation is lowlands.

The general geology of the study area consists of varying thickness of glacial drift on top of a bedrock shale. Glacial drift consists of till, glaciofluvial (stream) sediments, and glaciolacustrine (lake) sediments. Glacial till is a heterogeneous mixture of clay, silt, sand, gravel, and boulders, and is often very low in permeability. Glaciofluvial sediments include glacialoutwash deposits of sand and gravel deposited by flowing glacial meltwaters. Glaciolacustrine sediments are composed of layered deposits of clay, silt, and sand transported into ancient lakes by glacial meltwaters. Alluvium also may be found along recent flood plains or lakebeds, and generally consists of deposits of silt, sand, and gravel.

\section{DATA SETS}

Several data sets are available for the study area and are included on the CD-ROMs. Geospatial data are provided in Arc/Info coverages, which are compatible with several Geographical Information System (GIS) software packages. All geospatial coverages presented on the CD-ROMs are in the Albers Equal Area map projection, with projection information shown in table 1. Water-quality data are presented in a Microsoft Excel Spreadsheet (.xls) format. Pesticide-use data is provided in Adobe Acrobat (.pdf) format or hypertext markup language (.htm). A description and summary of each data set and relevance to a PMP is provided, along with any special comments regarding format on the CD-ROMs. The content of the CD-ROMs is outlined in the Supplemental Information section at the end of this report. 


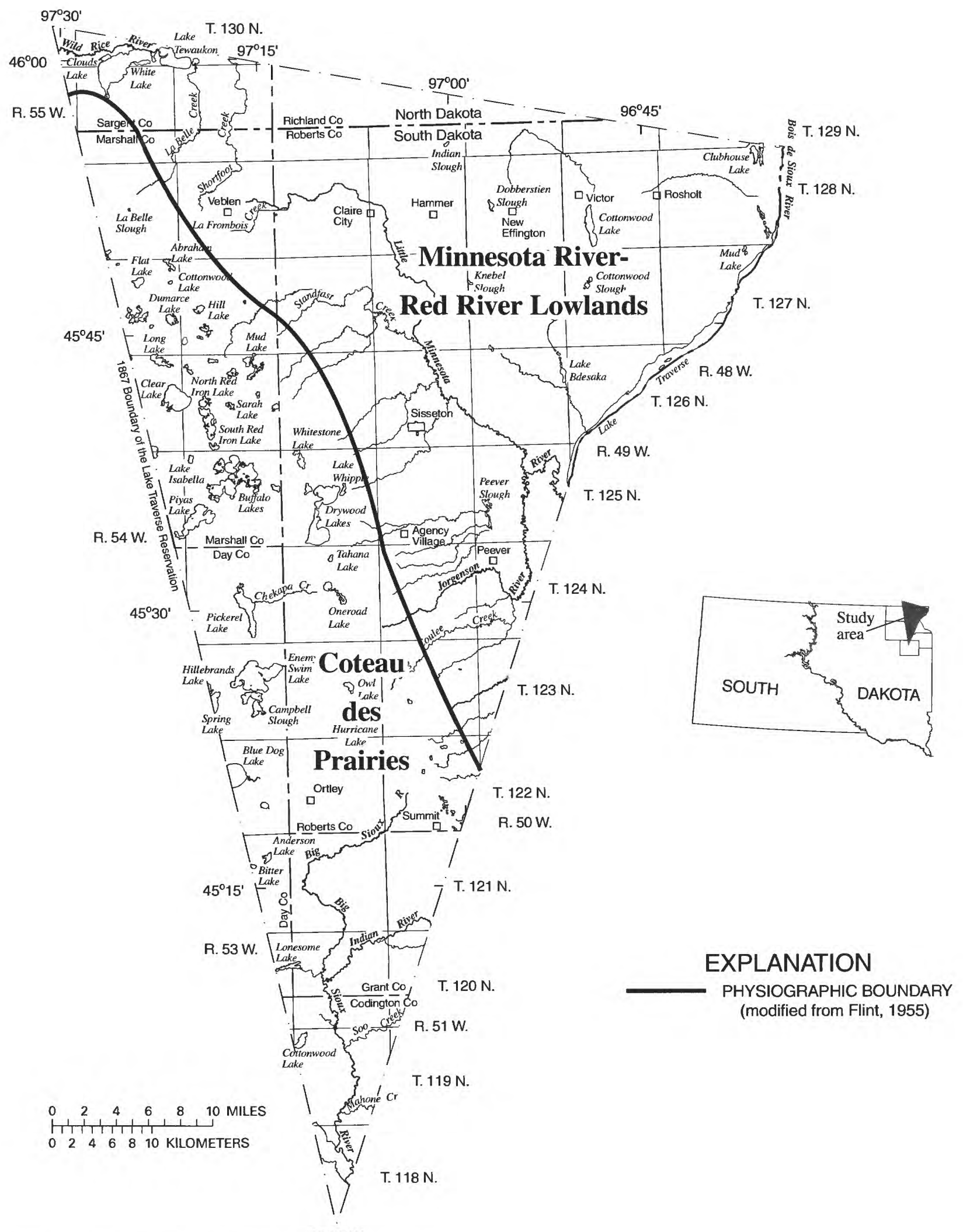

R. 52 W.

Base from U.S. Geological Survey digital line graph 1:100,000, 1993 Universal Transverse Mercator projection, zone 14

Figure 1. Location of the Lake Traverse Reservation. 
Table 1. Albers Equal Area projection parameters

[GRS 1980, Geodetic Reference System of 1980; NAD83, North American Datum of 1983]

\begin{tabular}{ll}
\hline & Projection Parameters \\
Spheroid & GRS 1980 \\
Datum & NAD83 \\
First standard parallel & $29^{\circ} 30^{\prime} 00^{\prime \prime}$ North \\
Second standard parallel & $45^{\circ} 30^{\prime} 00^{\prime \prime}$ North \\
Central meridian & $96^{\circ} 00^{\prime} 00^{\prime \prime}$ West \\
Latitude of projection origin $\quad$ Coordinate System Parameters \\
& 0 \\
False easting $\quad$ & 0 \\
False northing & \\
Planimetric units of measure & Meters \\
\hline
\end{tabular}

\section{Pesticide Concentrations in Ground Water and Surface Water}

The presence or absence of a certain pesticide in ground-water quality samples can be an indicator of aquifer sensitivity. If a given pesticide is not found, it may be that the pesticide does not easily enter ground water, or it may be that the pesticide was not used recently in the area where the sample was taken. When a pesticide is found in ground-water samples, the possibility for ground-water contamination exists at or near the sample collection area.

Ground water and surface water in the study area has been sampled for pesticides by the South Dakota Department of Environment and Natural Resources, Geological Survey Program (SDGS) and the USGS. SDGS sampled the Big Sioux River and the Indian River and nine observation wells within the study area (fig. 2). Table 2 summarizes pesticide concentrations measured in ground-water samples by the SDGS, and table 3 summarizes pesticide concentrations measured in surface-water samples. Because of differences in two laboratories used, and improvements in analytical methods over time for some constituents, the minimum reporting level is not consistent for all samples. In 1998 , as part of a water-resources investigation, the USGS sampled 13 observation wells within the study area for atrazine, carbofuran, cyanazine, and 2,4-D using enzyme-linked immunosorbent assay (ELISA) analysis (fig. 2) (Thompson, 2000). 2,4-D was measured at a concentration of $0.7 \mu \mathrm{g} / \mathrm{L}$ (microgram per liter) (detection limit) in ground water from one well. Pesticides were not detected in ground water from other wells.
Additional water-quality analyses for pesticides from earlier USGS studies were available from the USGS National Water Information System (NWIS) Database. A total of 113 pesticides and pesticide metabolites (table 4) were analyzed in samples from two wells and six lakes in or near the study area (fig. 2). Pesticides were detected in nine samples-three ground water and six surface water. Lindane was the most frequently detected pesticide of the six pesticides detected, at concentrations ranging from 0.01 to $0.03 \mu \mathrm{g} / \mathrm{L}$.

\section{Precipitation}

Precipitation data through 1996 (Carter and Thompson, 1998) and from 1997-99 (Thompson, 2000) for the Lake Traverse Reservation and Roberts County have been presented and were summarized by Thompson (2001). Seven of the eight National Weather Service (NWS) stations mentioned are within or near the Reservation boundary. Data for these seven stations for 2000-01 are presented in table 5 .

\section{Soils Data}

The transport of pesticides into ground water is governed in part by the physical and chemical properties of soil. Several factors, including soil $\mathrm{pH}$, organic carbon content, clay content, and infiltration rate can influence how much pesticide is adsorbed by soil. Three geospatial soil data sets are available for the study area-the State Soil Geographic Database (STATSGO), the Map Unit Interpretation Database (MUIR), and the Soils Survey Geographic Database (SSURGO). These soils data sets were developed by the U.S. Department of Agriculture, Natural Resource Conservation Service (NRCS).

The STATSGO geospatial data set was downloaded from the Internet on September 4, 2001, from URL http://water.usgs.gov/lookup/getspatial?muid and are provided on the CD-ROM as an ARC/INFO coverage in the soils directory. Soils information contained in the STATSGO database for North and South Dakota was produced at a map scale of 1:250,000. This data set is generalized and is intended for broad planning and management uses covering State, regional, and multiState areas (Natural Resources Conservation Service, 2000). The database for the STATSGO coverage is provided in the info files of the coverage. Polygons in the STATSGO coverage are linked to the database records by the map unit identifier. 


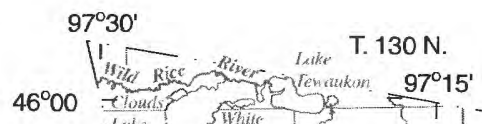

R. 55 W

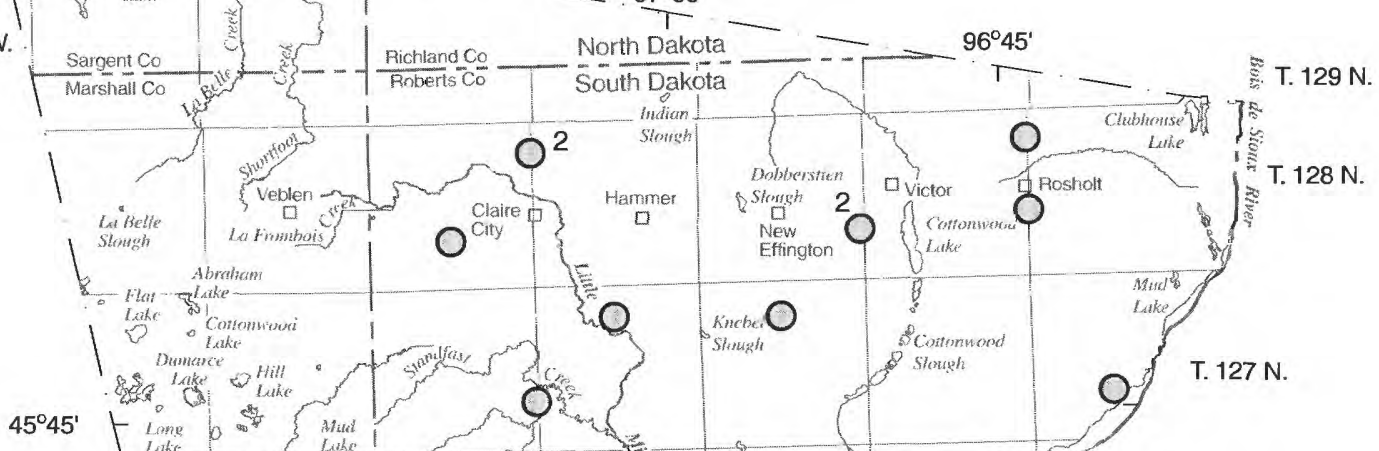

R. 54 W.

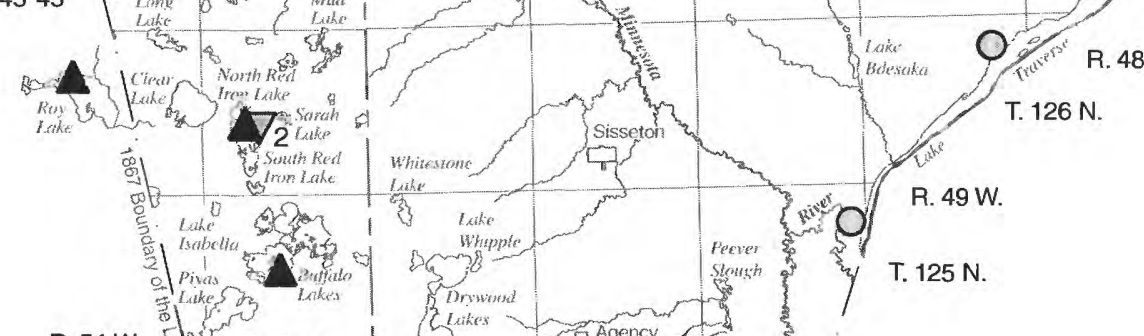

क्षे

$45^{\circ} 30^{\prime}$

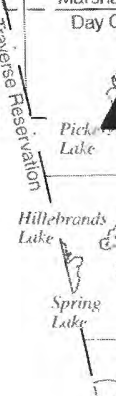

$\stackrel{0}{1}, 2,4,6,8,10$ MILES

$\begin{array}{lllllll}0 & 2 & 4 & 6 & 8 & 10 & \text { KILOMETERS }\end{array}$ 
Table 2. Summary of pesticide concentrations measured in ground-water samples collected by the South Dakota Geological Survey in the study area

[ $\mu \mathrm{g} / \mathrm{L}$, micrograms per liter, ELISA, enzyme-linked immunosorbent assay]

\begin{tabular}{|c|c|c|c|c|}
\hline $\begin{array}{l}\text { Pesticides and pesticide } \\
\text { metabolites }\end{array}$ & $\begin{array}{c}\text { Number of } \\
\text { analyses }\end{array}$ & $\begin{array}{c}\text { Number of } \\
\text { detections } \\
\text { above } \\
\text { minimum } \\
\text { reporting } \\
\text { level }\end{array}$ & $\begin{array}{l}\text { Minimum reporting level }(\mu \mathrm{g} / \mathrm{L}) \text {, } \\
\text { number of analyses below } \\
\text { respective level }\end{array}$ & $\begin{array}{c}\text { Range of } \\
\text { detected values } \\
(\mu g / L)\end{array}$ \\
\hline Acetochlor & 66 & 0 & $0.1,29 ; 0.2,7 ; 0.5,29 ; 20,1$ & -- \\
\hline Alachlor & 95 & 1 & $0.1,92 ; 0.2,1 ; 10,1$ & 0.141 \\
\hline Alachlor (ELISA) & 25 & 1 & $0.1,24$ & 0.1 \\
\hline Atrazine & 95 & 5 & $0.1,90$ & $0.13-0.34$ \\
\hline Atrazine (ELISA) & 51 & 20 & $0.1,31$ & $0.1-0.7$ \\
\hline Bentazon & 88 & 0 & $0.1,1 ; 0.2,49 ; 1,7 ; 2,31$ & - \\
\hline Bromoxynil & 47 & 0 & $0.2,23 ; 1,7 ; 2,17$ & -- \\
\hline Butylate & 58 & 0 & $0.1,49 ; 0.5,9$ & -- \\
\hline Carbofuran & 54 & 0 & $0.1,53 ; 0.5,1$ & -- \\
\hline Chlorpyrifos & 31 & 0 & $0.1,24 ; 0.2,7$ & -- \\
\hline Cyanazine & 93 & 0 & $0.1,63 ; 1,29 ; 2,1$ & -- \\
\hline Cyanazine (ELISA) & 26 & 0 & $0.1,26$ & -- \\
\hline 2,4-D (2,4-dichlorophenoxyacetic acid) & 95 & 0 & $0.2,50 ; 1,7 ; 2,38$ & -- \\
\hline 2,4-D (ELISA) & 48 & 0 & $0.1,1 ; 1,47$ & -- \\
\hline $\begin{array}{l}\text { DCPA (dimethyl-2,3,5,6-tetrachloro- } \\
\text { terephthalate) }\end{array}$ & 12 & 0 & $0.05,3 ; 0.5,9$ & -- \\
\hline Desethyl Atrazine & 57 & 3 & $0.1,54$ & $0.12-0.52$ \\
\hline Desisopropyl Atrazine & 55 & 1 & $0.1,9 ; 0.5,14 ; 2,31$ & 0.16 \\
\hline Dicamba & 95 & 0 & $0.2,50 ; 1,7 ; 2,38$ & -- \\
\hline $\begin{array}{l}\text { EPTC ( } S \text {-ethyldi-N, } N \text {-propylthio- } \\
\text { carbamate) }\end{array}$ & 91 & 1 & $0.1,49 ; 0.2,5 ; 0.4,7 ; 0.5,29$ & 0.11 \\
\hline Ethalfluralin & 45 & 0 & $0.05,3 ; 0.1,23 ; 0.2,1 ; 0.4,7 ; 0.5,11$ & -- \\
\hline Ethoprop & 24 & 0 & $0.1,24$ & -- \\
\hline Fonofos & 56 & 0 & $0.1,46 ; 0.2,1 ; 0.5,9$ & -- \\
\hline Glyphosate & 3 & 0 & 20,3 & - \\
\hline Imazethapyr & 9 & 0 & 10,9 & -- \\
\hline $\begin{array}{l}\text { MCPA (2-methyl-4-chlorophenoxyacetic } \\
\text { acid) }\end{array}$ & 95 & 0 & $0.5,31 ; 2,7 ; 2.5,7 ; 200,50$ & -- \\
\hline Metolachlor & 93 & 2 & $0.1,89 ; 2,1 ; 10,1$ & $0.102-0.137$ \\
\hline Metolachlor (ELISA) & 26 & 2 & $0.1,24$ & 0.3 \\
\hline Metribuzin & 87 & 27 & $0.1,49 ; 0.2,10 ; 0.5,27 ; 10,1$ & -- \\
\hline Parathion & 47 & 0 & $0.1,26 ; 0.2,7 ; 0.5,13 ; 2,1$ & -- \\
\hline Pendimethalin & 67 & 0 & $0.1,48 ; 0.2,7 ; 0.5,11 ; 10,1$ & -- \\
\hline
\end{tabular}


Table 2. Summary of pesticide concentrations measured in ground-water samples collected by the South Dakota Geological Survey in the study area-Continued

$[\mu \mathrm{g} / \mathrm{L}$, micrograms per liter, ELISA, enzyme-linked immunosorbent assay]

\begin{tabular}{lcccc}
\hline \multicolumn{1}{c}{$\begin{array}{c}\text { Pesticides and pesticide } \\
\text { metabolites }\end{array}$} & $\begin{array}{c}\text { Number of } \\
\text { analyses }\end{array}$ & $\begin{array}{c}\text { Number of } \\
\text { detections } \\
\text { above } \\
\text { minimum } \\
\text { reporting } \\
\text { level }\end{array}$ & $\begin{array}{c}\text { Minimum reporting level }(\mu \mathrm{g} / \mathrm{L}), \\
\text { number of analyses below } \\
\text { respective level }\end{array}$ & $\begin{array}{c}\text { Range of } \\
\text { detected values } \\
(\mu \mathrm{\mu g} / \mathrm{L})\end{array}$ \\
\hline Phorate & 24 & 0 & $0.1,24$ & -- \\
Picloram & 74 & 0 & $0.2,47 ; 1,7 ; 2,20$ & -- \\
Prometon & 9 & 0 & 2,9 & -- \\
Simazine & 52 & 1 & $0.1,51$ & -122 \\
Terbufos & 24 & 0 & $0.1,24$ & -- \\
$2,4,5-T P$ & 27 & 0 & $0.2,27$ & -- \\
Triasulfuron & 3 & 0 & $0.05,3$ & - \\
Trifluralin & 95 & 0 & $0.1,50 ; 0.2,7 ; 0.5,38$ & - \\
\hline
\end{tabular}

Table 3. Pesticide concentrations measured in surface-water samples collected by the South Dakota Geological Survey in the study area

[Method of analysis was enzyme-linked immunosorbent assay (ELISA). $\mu \mathrm{g} / \mathrm{L}$, micrograms per liter; <, less than]

\begin{tabular}{lcccc}
\hline \multicolumn{1}{c}{ Site } & $\begin{array}{c}\text { Sampling } \\
\text { date }\end{array}$ & $\begin{array}{c}\text { Atrazine } \\
(\boldsymbol{\mu g} / \mathbf{L})\end{array}$ & $\begin{array}{c}\mathbf{2 , 4 - D} \\
(\boldsymbol{\mu g} / \mathbf{L})\end{array}$ & $\begin{array}{c}\text { Alachlor } \\
(\boldsymbol{\mu g} / \mathbf{L})\end{array}$ \\
\hline Big Sioux River & $5-25-93$ & $<0.1$ & $<1.0$ & $<1.0$ \\
& $6-21-93$ & .5 & 7.5 & .3 \\
& $7-19-93$ & 1.5 & $<1.0$ & .9 \\
& $8-30-93$ & .1 & $<1.0$ & .1 \\
Indian River & $5-25-93$ & .3 & $<1.0$ & $<1.0$ \\
& $6-21-93$ & .4 & 1.7 & .5 \\
& $7-19-93$ & .5 & 1.0 & .3 \\
& $8-30-93$ & .1 & $<1.0$ & $<1.0$ \\
\hline
\end{tabular}


Table 4. Summary of pesticide analyses retrieved from National Water Information System Database on March 13, 2002

[ $\mu \mathrm{g} / \mathrm{L}$, micrograms per liter; filtered, 0.7-micron glass fiber filter; --, not applicable; NA, not available]

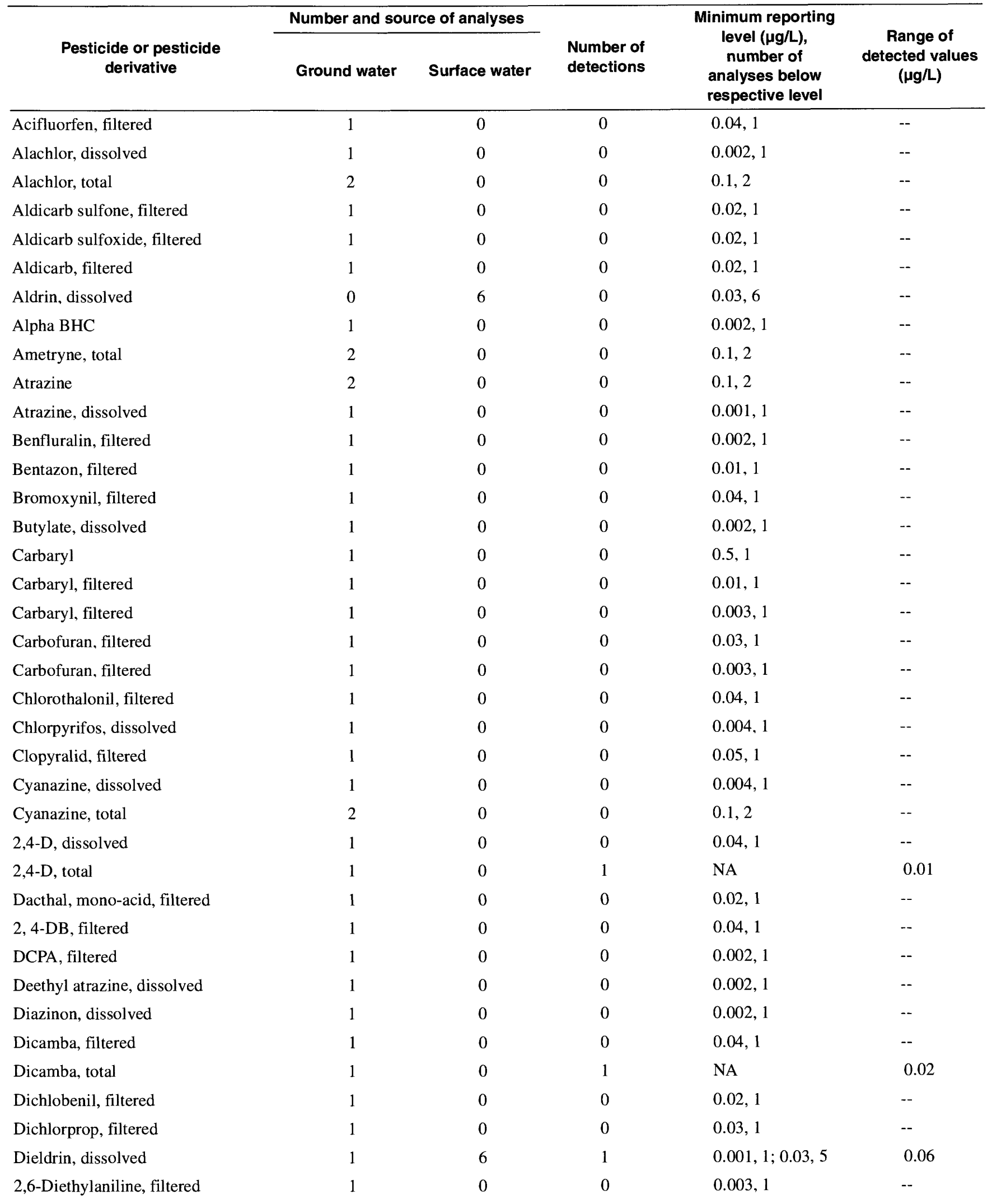


Table 4. Summary of pesticide analyses retrieved from National Water Information System Database on March 13, 2002-Continued

[ $\mu \mathrm{g} / \mathrm{L}$, micrograms per liter; filtered, 0.7-micron glass fiber filter; --, not applicable; NA, not available]

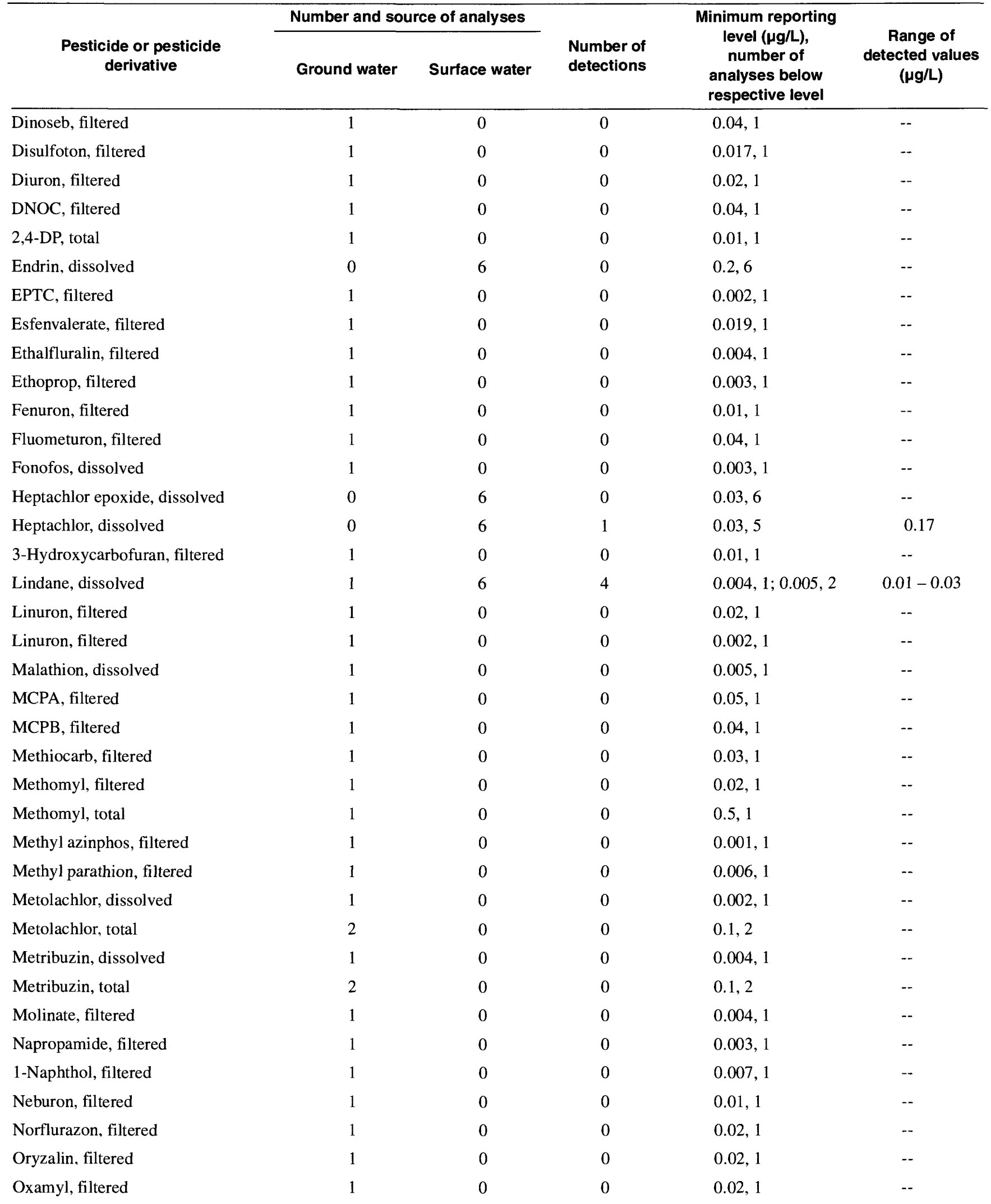


Table 4. Summary of pesticide analyses retrieved from National Water Information System Database on March 13, 2002-Continued

[ $\mu \mathrm{g} / \mathrm{L}$, micrograms per liter; filtered, 0.7-micron glass fiber filter; --, not applicable; NA, not available]

\begin{tabular}{|c|c|c|c|c|c|}
\hline \multirow{2}{*}{$\begin{array}{l}\text { Pesticide or pesticide } \\
\text { derivative }\end{array}$} & \multicolumn{2}{|c|}{ Number and source of analyses } & \multirow{2}{*}{$\begin{array}{l}\text { Number of } \\
\text { detections }\end{array}$} & \multirow{2}{*}{$\begin{array}{l}\text { Minimum reporting } \\
\text { level ( } \mu \mathrm{g} / \mathrm{L}), \\
\text { number of } \\
\text { analyses below } \\
\text { respective level }\end{array}$} & \multirow{2}{*}{$\begin{array}{c}\text { Range of } \\
\text { detected values } \\
(\mu \mathrm{g} / L)\end{array}$} \\
\hline & Ground water & Surface water & & & \\
\hline P, P' DDE, dissolved & 1 & 0 & 0 & $0.006,1$ & -- \\
\hline P, P'-DDD & 0 & 6 & 0 & $0.05,6$ & -- \\
\hline P, P'-DDE & 0 & 6 & 1 & $0.03,5$ & 0.19 \\
\hline P, P'-DDT & 0 & 6 & 0 & $0.25,6$ & -- \\
\hline Parathion, dissolved & 1 & 0 & 0 & $0.004,1$ & -- \\
\hline Pebulate, filtered & 1 & 0 & 0 & $0.004,1$ & -- \\
\hline Pendimethalin, filtered & 1 & 0 & 0 & $0.004,1$ & -- \\
\hline Permethrin, cis, filtered & 1 & 0 & 0 & $0.005,1$ & - \\
\hline Phorate, filtered & 1 & 0 & 0 & $0.002,1$ & -- \\
\hline Picloram & 1 & 0 & 0 & $0.01,1$ & -- \\
\hline Picloram, filtered & 1 & 0 & 0 & $0.05,1$ & -- \\
\hline Prometon, dissolved & 1 & 0 & 0 & $0.018,1$ & -- \\
\hline Prometone, total & 2 & 0 & 0 & $0.1,2$ & - \\
\hline Prometryne, total & 2 & 0 & 0 & $0.1,2$ & - \\
\hline Pronamide, filtered & 1 & 0 & 0 & $0.003,1$ & -- \\
\hline Propachlor, dissolved & 1 & 0 & 0 & $0.007,1$ & -- \\
\hline Propanil, filtered & 1 & 0 & 0 & $0.004,1$ & -- \\
\hline Propargite, filtered & 1 & 0 & 0 & $0.013,1$ & -- \\
\hline Propazine, total & 2 & 0 & 0 & $0.1,2$ & - \\
\hline Propham, filtered & 1 & 0 & 0 & $0.04,1$ & -- \\
\hline Propham, total & 1 & 0 & 0 & $0.5,1$ & -- \\
\hline Propoxur, filtered & 1 & 0 & 0 & $0.04,1$ & -- \\
\hline Silvex, dissolved & 1 & 0 & 0 & $0.02,1$ & -- \\
\hline Silvex, total & 1 & 0 & 0 & $0.01,1$ & -- \\
\hline Simazine, dissolved & 1 & 0 & 0 & $0.005,1$ & -- \\
\hline Simazine, total & 2 & 0 & 0 & $0.1,2$ & -- \\
\hline Simetryne, total & 2 & 0 & 0 & $0.1,2$ & -- \\
\hline 2,4,5-T, dissolved & 1 & 0 & 0 & $0.04,1$ & - \\
\hline $2,4,5-\mathrm{T}$, total & 1 & 0 & 0 & $0.01,1$ & -- \\
\hline Tebuthiuron, filtered & 1 & 0 & 0 & $0.01,1$ & - \\
\hline Terbacil, filtered & 1 & 0 & 0 & $0.007,1$ & -- \\
\hline Terbufos, filtered & 1 & 0 & 0 & $0.013,1$ & - \\
\hline Thiobencarb, filtered & 1 & 0 & 0 & $0.02,1$ & -- \\
\hline Triallate, filtered & 1 & 0 & 0 & $0.001,1$ & -- \\
\hline Triclopyr, filtered & 1 & 0 & 0 & $0.05,1$ & -- \\
\hline Trifluralin, filtered & 1 & 0 & 0 & $0.002,1$ & -- \\
\hline Trifluralin, total & 2 & 0 & 0 & $0.1,2$ & -- \\
\hline
\end{tabular}


Table 5. Precipitation, in inches, for 2000-01 for seven National Weather Service stations within and near the Lake Traverse Reservation

\begin{tabular}{|c|c|c|c|c|c|c|c|c|c|c|c|c|c|}
\hline Year & Jan. & Feb. & Mar. & Apr. & May & June & July & Aug. & Sep. & Oct. & Nov. & Dec. & Annual \\
\hline \multicolumn{14}{|c|}{ Sisseton, South Dakota } \\
\hline 2000 & 0.40 & 1.74 & 1.82 & 3.34 & 1.25 & 2.91 & 4.68 & 1.28 & 0.92 & 0.60 & 3.45 & 1.18 & 23.57 \\
\hline 2001 & .13 & 1.26 & .30 & 4.31 & 3.36 & 2.55 & 4.16 & .92 & 2.67 & 1.77 & 1.79 & .03 & 23.25 \\
\hline \multicolumn{14}{|c|}{ Summit, South Dakota } \\
\hline 2000 & .23 & .86 & .62 & 2.24 & 1.71 & 2.40 & 4.77 & .99 & 1.36 & .90 & 4.52 & .65 & 21.25 \\
\hline 2001 & .98 & 1.13 & .02 & 4.99 & 3.13 & 5.03 & 3.79 & .34 & 3.08 & 2.16 & 1.23 & .06 & 25.94 \\
\hline \multicolumn{14}{|c|}{ Victor, South Dakota } \\
\hline 2000 & .58 & .92 & 1.03 & 1.84 & 2.59 & 2.83 & 5.13 & .51 & 1.33 & .62 & 3.83 & .82 & 22.03 \\
\hline 2001 & .98 & 1.02 & .41 & 3.70 & 2.52 & 5.34 & 3.32 & 2.64 & 3.14 & 2.09 & 1.34 & .25 & 26.75 \\
\hline \multicolumn{14}{|c|}{ Watertown, South Dakota } \\
\hline 2000 & .19 & .54 & .72 & 1.55 & 2.51 & 3.89 & 4.11 & 1.31 & 1.10 & 1.62 & 2.31 & .64 & 20.49 \\
\hline 2001 & 1.04 & .04 & 1.04 & 6.48 & 2.60 & 2.75 & 3.37 & .50 & 2.33 & .76 & 1.31 & .07 & 22.29 \\
\hline \multicolumn{14}{|c|}{ Waubay National Wildlife Refuge, South Dakota } \\
\hline 2000 & .39 & .54 & .68 & 2.52 & 1.07 & 1.77 & 5.37 & 1.01 & 1.11 & .83 & 3.12 & .62 & 19.03 \\
\hline 2001 & .58 & .86 & .29 & 3.97 & 2.49 & 4.57 & 3.54 & .48 & 2.19 & 1.71 & .79 & .07 & 21.54 \\
\hline \multicolumn{14}{|c|}{ Wilmot, South Dakota } \\
\hline 2000 & .53 & 1.21 & .67 & 2.82 & 2.19 & 2.27 & 4.58 & .66 & 1.43 & .68 & 3.81 & .66 & 21.51 \\
\hline 2001 & 1.53 & 1.68 & .46 & 6.93 & 2.83 & 5.72 & 3.48 & .67 & 2.15 & .64 & 1.30 & .08 & 27.47 \\
\hline \multicolumn{14}{|c|}{ Forman, North Dakota } \\
\hline 2000 & .30 & .85 & 1.40 & 1.70 & 3.13 & 3.03 & 6.02 & 1.39 & 1.35 & .42 & 2.95 & .73 & 23.27 \\
\hline 2001 & .16 & 1.06 & .12 & 3.85 & 1.60 & 4.16 & 4.38 & 1.90 & 3.54 & 2.41 & .80 & .31 & 24.29 \\
\hline
\end{tabular}

The MUIR database provided in the soils directory on the CD-ROM is derived from the Soil Interpretations Record (SIR) database. The SIR database contains information specific to each individual component soil, while the MUIR database contains approximately 88 estimated physical and chemical soil properties, interpretations, and crop performance data for soil map units made up of a composite of the individual component soils present in the map unit. The MUIR database was downloaded from the Internet on August 2, 2001, from URL http:// www.statlab.iastate.edu/cgi-bin/dmuir.cgi. The MUIR soils attribute database in the study area is at scales ranging from $1: 12,000$ to $1: 31,680$ and is intended for use by landowners and local governments for planning purposes. The MUIR database is provided in two formats. A set of Excel files containing MUIR data for the study area is in the MUIR directory. In this format, the mapunit symbol (musym) is a column header in the spreadsheets used to relate the MUIR data to the soil polygons in the SSURGO coverage. The MUIR databases for each county also are provided separately as info files associated with the SSURGO coverage for each county in separate directories.

The SSURGO data were downloaded from the Internet on August 2, 2001, from URL http:// www.ftw.nrcs.usda.gov/ssurgo_ftp3.html. SSURGO is the most detailed level of soil maps produced by NRCS at scales ranging from 1:12,000 to 1:24,000. These data are suitable for use by the landowner and for natural- 
resources planning at the township, county, or similar level. Because not all the county soil maps within the study area have been digitized, SSURGO data were available only for Grant, Marshall, and Roberts Counties in South Dakota, and Sargent County in North Dakota. SSURGO data currently are being developed for the remaining counties in the study area, and will be available for download upon completion. SSURGO data are provided county by county in the SSURGO directory on the CD-ROM. The county coverages could not be appended to form a single coverage because edgematching between North Dakota and South Dakota counties has not been completed. STATSGO data may be substituted where possible until then.

\section{Topographic Data}

Topographic data for the study area is from the USGS 10-meter Digital Elevation Model (DEM) and is available on the CD-ROM. The DEM can be used to determine the altitude of the land surface at any point within the study area. Slope determinations also can be made, which is a determining factor in the amount of runoff. Precipitation that falls on an area with a high slope is more likely to run off into surface water than to infiltrate into an aquifer. The DEM also can be used to determine drainage patterns, delineate drainage basins, and generate summary statistics, such as minimum, maximum, and mean elevations for selected areas.

To use DEMs in such a manner, the individual DEMs, which usually are developed in 7.5 -minute by 7.5-minute sections similar to quadrangle maps, must be joined together, edgematched, and filled if necessary. This has already been done with the DEMs for the study area. Next a flow direction must be established for each 10-meter grid cell within the DEM. This can be accomplished with the "flowdirection" function in ARC/INFO GRID software (Environmental Systems Research Institute, Inc., 2000). After flow directions are established, flow accumulation for each cell can be accomplished using the "flowaccumulation" function in GRID. Flow accumulation is essentially the number of other cells that will eventually drain through each cell in the DEM. A stream network then can be generated using the "streamline" function in GRID, and by choosing an outlet of interest, all points upstream of the outlet form a basin. The basin area can be determined using the "watershed" function in GRID, and a boundary polygon can then be determined, along with basin properties.

Topography, streams, roads, towns, and jurisdictional boundaries are available from USGS Digital Raster Graphics (DRG). DRGs are scanned images of USGS 7.5-minute quadrangle maps that have been georeferenced. A list of DRGs covering the study area is given in table 6, and index locations are shown in figure 3. A "seamless" effect can be achieved in ArcView by turning off the background color (and other colors as needed) in each block displayed.

\section{Geohydrologic Data}

Geohydrologic data from Thompson (2001) for aquifers and outwash deposits in the study area include location, depth to top, thickness, and potentiometric contours or hydraulic head where available. A summary of the various geohydrologic data available is presented in table 7 . The data sets from Thompson (2001) include data for geohydrologic features outside the study area. Boundary polygons listed in table 7 are for aquifers and outwash groups within the Reservation and can be used to clip data sets extending beyond the study area boundaries. Because the extent of the named outwash groups are less definite, they are enclosed within a likelihood boundary, where sand and gravel deposits are more likely to be found inside the estimated boundary than outside. A boundary for the Dakota aquifer is not provided because it is thought to underlie the entire study area (Erickson, 1955). Hydrographs for the observation wells used to determine hydraulic head are indexed in Thompson (2001) and were presented in Carter and Thompson (1998) and Thompson (2000). Some of the aquifers and outwash deposits are deep and confined, whereas others are at or near land surface. The coverages in table 7 can be used to determine which areas have shallow aquifers and are more vulnerable to pesticide contamination than areas underlain by deep aquifers, or where aquifers or outwash deposits are absent. 
Table 6. Index of Digital Raster Graphics filenames and U.S. Geological Survey 7.5-minute quadrangle map names [DRG, Digital Raster Graphics; USGS, U.S. Geological Survey]

\begin{tabular}{|c|c|c|c|c|c|}
\hline $\begin{array}{l}\text { Index number } \\
\text { from figure } 3\end{array}$ & $\begin{array}{c}\text { DRG } \\
\text { filename }\end{array}$ & $\begin{array}{l}\text { USGS } 7.5 \text {-minute } \\
\text { quadrangle name }\end{array}$ & $\begin{array}{l}\text { Index number } \\
\text { from figure } 3\end{array}$ & $\begin{array}{c}\text { DRG } \\
\text { filename }\end{array}$ & $\begin{array}{l}\text { USGS 7.5-minute } \\
\text { quadrangle name }\end{array}$ \\
\hline 1 & O46097A5 & Rutland, N. Dak. & 24 & $\mathrm{O} 45096 \mathrm{~F} 8$ & Peever NW, S. Dak. \\
\hline 2 & O46097A4 & Cayuga, N. Dak. & 25 & $\mathrm{O} 45096 \mathrm{~F} 7$ & Peever NE, S. Dak.-Minn. \\
\hline 3 & O46097A3 & Geneseo, N. Dak. & 26 & O45096F6 & Beardsley NW, Minn.-S. Dak. \\
\hline 4 & $\mathrm{O} 45097 \mathrm{H} 4$ & Marlow, N. Dak.-S. Dak. & 27 & $\mathrm{O} 45097 \mathrm{E} 4$ & Eden, S. Dak. \\
\hline 5 & $\mathrm{O} 45097 \mathrm{H} 3$ & Veblen NE, N. Dak.-S. Dak & 28 & O45097E3 & Piyas Lake, S. Dak. \\
\hline 6 & $\mathrm{O} 45097 \mathrm{H} 2$ & Claire City NW, N. Dak.-S. Dak. & 29 & O45097E2 & Drywood Lakes, S. Dak. \\
\hline 7 & $\mathrm{O} 45097 \mathrm{H} 1$ & Claire City NE, N. Dak.-S. Dak. & 30 & $\mathrm{O} 45097 \mathrm{E} 1$ & Goodwill, S. Dak. \\
\hline 8 & $\mathrm{O} 45096 \mathrm{H} 8$ & New Effington NW, N. Dak.-S. Dak. & 31 & $\mathrm{O} 45096 \mathrm{E} 8$ & Peever, S. Dak. \\
\hline 9 & $\mathrm{O} 45096 \mathrm{H} 7$ & New Effington NE, N. Dak.-S. Dak. & 32 & $\mathrm{O} 45096 \mathrm{E} 7$ & Browns Valley, S. Dak.-Minn. \\
\hline 10 & $\mathrm{O} 45096 \mathrm{H} 6$ & La Mars, N. Dak.-S. Dak. & 33 & O45097D3 & Enemy Swim Lake West, S. Dak. \\
\hline 11 & O45096H5 & Boisberg, Minn.-N. Dak.-S. Dak. & 34 & O45097D2 & Enemy Swim Lake East, S. Dak. \\
\hline 12 & O45097G4 & Hillhead, S. Dak. & 35 & O45097D1 & Summit NE, S. Dak. \\
\hline 13 & $\mathrm{O} 45097 \mathrm{G} 3$ & Veblen, S. Dak. & 36 & O45096D8 & Wilmot NW, S. Dak. \\
\hline 14 & $\mathrm{O} 45097 \mathrm{G} 2$ & Claire City SW, S. Dak. & 37 & $\mathrm{O} 45097 \mathrm{C} 3$ & Waubay, S. Dak. \\
\hline 15 & $\mathrm{O} 45097 \mathrm{G} 1$ & Claire City, S. Dak. & 38 & $\mathrm{O} 45097 \mathrm{C} 2$ & Ortley, S. Dak. \\
\hline 16 & O45096G8 & New Effington, S. Dak. & 39 & $\mathrm{O} 45097 \mathrm{Cl}$ & Summit, S. Dak. \\
\hline 17 & O45096G7 & Victor, S. Dak. & 40 & $\mathrm{O} 45096 \mathrm{C} 8$ & Marvin, S. Dak. \\
\hline 18 & O45096G6 & Rosholt, S. Dak.-Minn. & 41 & O45097B3 & Florence, S. Dak. \\
\hline 19 & O45096G5 & Wheaton West, Minn.-S. Dak. & 42 & $\mathrm{O} 45097 \mathrm{~B} 2$ & Lonesome Lake, S. Dak. \\
\hline 20 & O45097F4 & Lake City, S. Dak. & 43 & O45097B1 & Still Lake NE, S. Dak. \\
\hline 21 & O45097F3 & South Red Iron Lake, S. Dak. & 44 & O45097A2 & Still Lake, S. Dak. \\
\hline 22 & $\mathrm{O} 45097 \mathrm{~F} 2$ & Whitestone Lake, S. Dak. & 45 & O45097A1 & Still Lake SE, S. Dak. \\
\hline 23 & O45097F1 & Sisseton, S. Dak. & 46 & $\mathrm{O} 44097 \mathrm{H} 2$ & Watertown West, S. Dak. \\
\hline
\end{tabular}




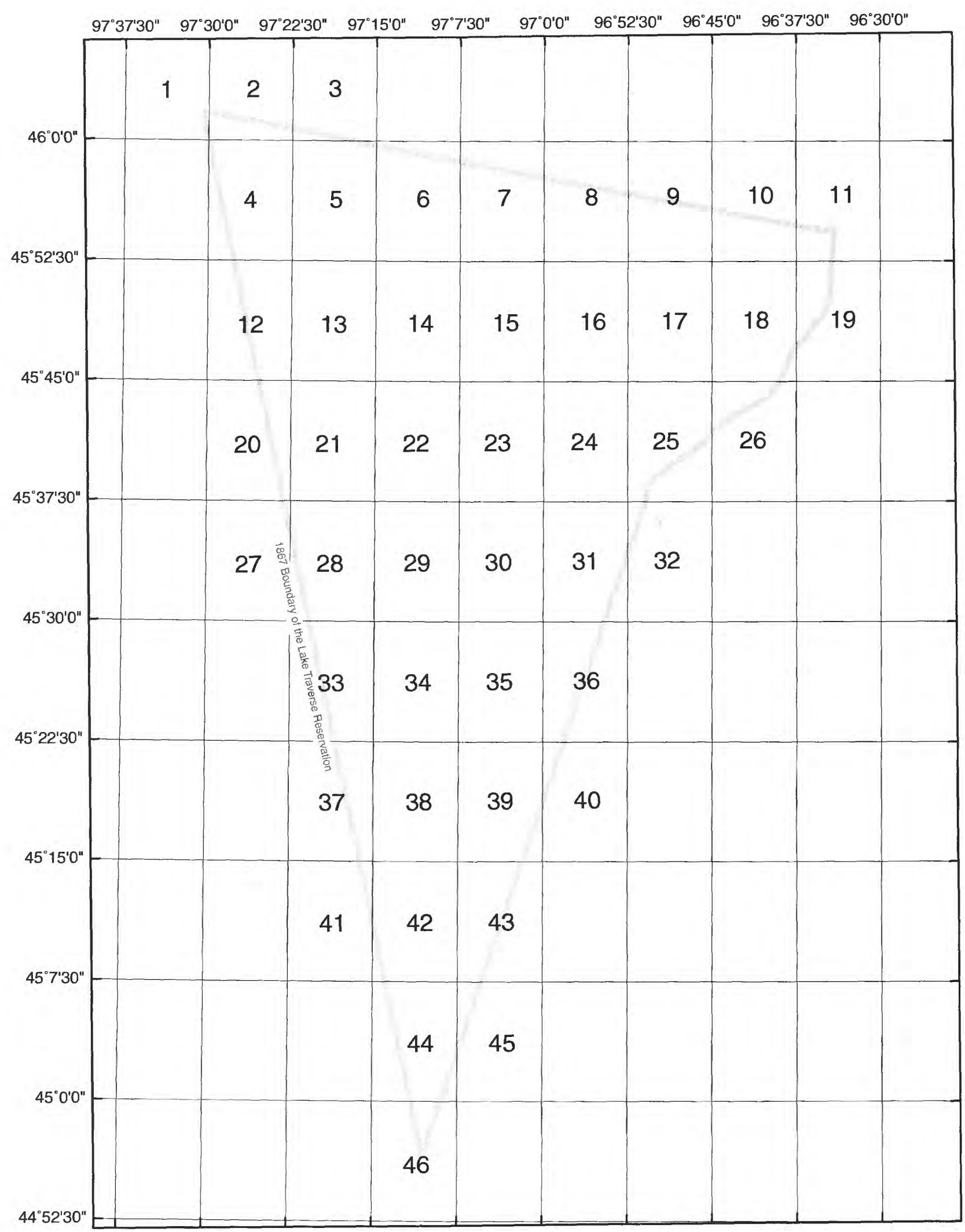

Figure 3. Index map of 7.5-minute Digital Raster Graphic (DLG) locations. Index numbers correspond to table 6. 
Table 7. Summary of geohydrologic data sets for aquifers and outwash in the study area

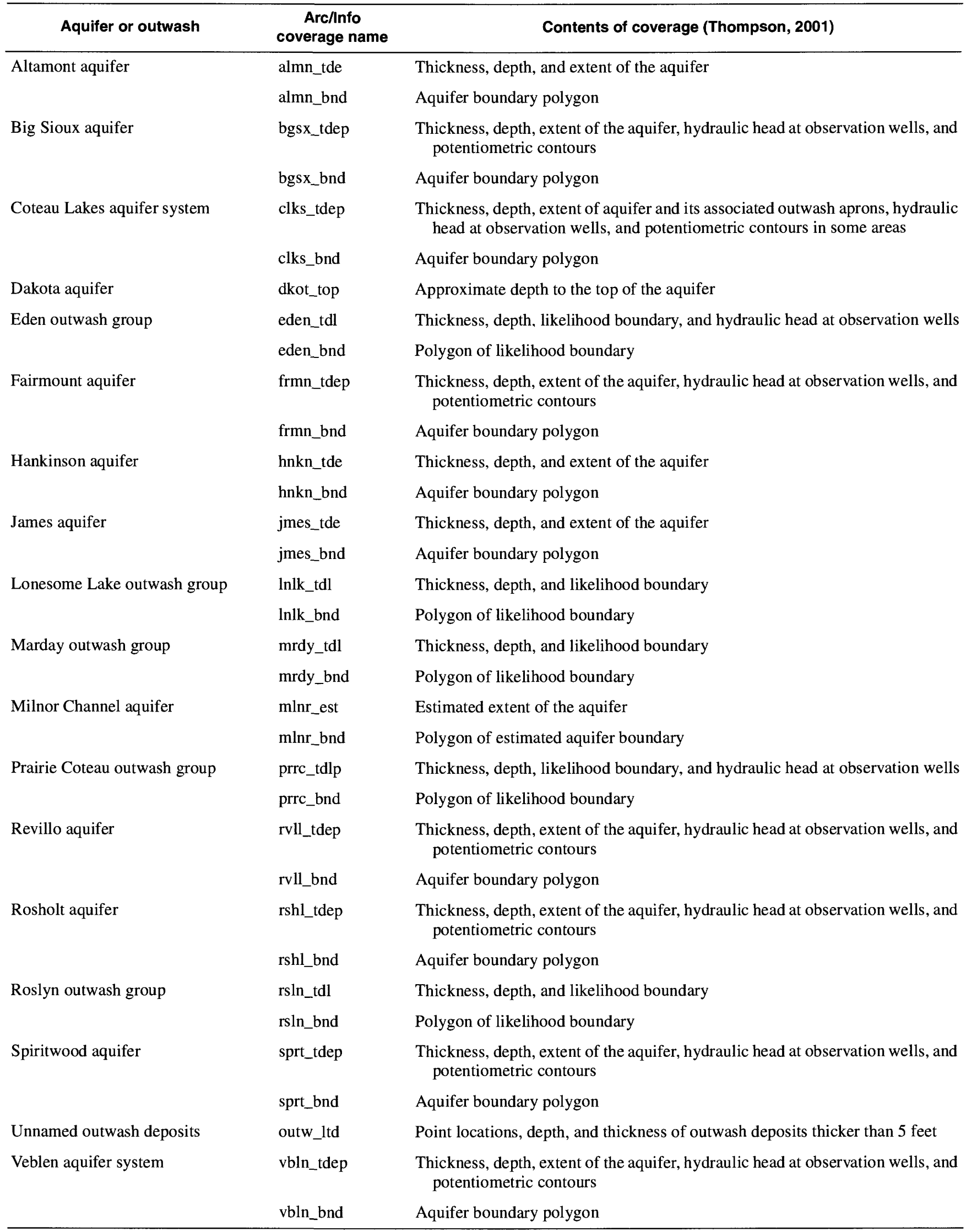




\section{Land Cover and Use}

Land-cover data were developed for the MultiResolution Land Characteristics Consortium, an interagency project involving multiple divisions of the USGS, the USEPA, the National Oceanographic and Atmospheric Administration, and the U.S. Department of Agriculture, Forest Service. The National Land Cover data sets are high-resolution (30-by-30 meters) digital data describing land cover for the conterminous United States. Twenty-one general land-cover classes were developed for mapping 30-meter Landsat thematic mapper satellite data. Only 17 of the 21 landcover classes were present within the study area. The data are organized by State and were downloaded with the metadata from the Internet on August 2, 2001, at URL http://www.epa.gov/mrlc/nlcd.html. The National Land Cover data sets for South and North Dakota were preliminary at the time this study was completed. Therefore, the accuracy assessment of the data set was not completed. Land-use and land-cover data can be used to determine where pesticides and fertilizers are likely to be applied, where crops are irrigated, and where urban development is located. Land cover and use for the clipped coverage of the study area are summarized in table 8 .

\section{Pesticide Use}

Pesticide use within the study area is mainly to control weeds and insects on crops, although fungicides and nematocides may be used on certain crops. Information describing pesticide usage in the study area or parts of it were available from four sources. Statewide pesticide-use data for South Dakota are available from the U.S. Department of Agriculture, South Dakota Agricultural Statistics Service (SDASS) (2001). Pesticide-use data in 1987 by county for South Dakota are available from the USGS (Battaglin and Goolsby, 1994). Pesticide-use data for South Dakota in 1994 by crop and crop-reporting district also are published by South Dakota State University (Ruden, 1994). A pesticide-use database for 1992 and 1997 is searchable by pesticide type, region, State, and crop (National Center for Food and Agricultural Policy, 2001). A description of the pesticide-use data from each source and its format on the CD-ROM follows.

The Lake Traverse Reservation encompasses parts of seven counties in South and North Dakota, with the majority of cropland in Roberts County, South Dakota. For this reason, Roberts County was chosen to represent the study area for data summarized by

Table 8. Land cover and use in the study area

\begin{tabular}{lrr}
\hline \multicolumn{1}{c}{ Land use } & Acres & Percent \\
\hline Open water & $28,866.0$ & 2.99 \\
Low intensity residential (most commonly single-family housing) & 378.1 & 0.04 \\
High intensity residential (apartment complexes and row houses) & 436.3 & 0.05 \\
Commercial/industrial/transportation (infrastructure, such as roads and railroads) & $2,577.7$ & 0.27 \\
Quarries/strip mines/gravel pits & 70.7 & 0.01 \\
Transitional (areas of sparse vegetative cover that are changing from one cover type to another) & 0.2 & 0.00 \\
Deciduous forest & $17,023.7$ & 1.76 \\
Evergreen forest & 69.2 & 0.01 \\
Mixed forest & 185.7 & 0.02 \\
Shrubland & 2.2 & 0.00 \\
Grasslands/herbaceous plants (grasses and forbs often utilized for grazing) & $60,875.8$ & 6.31 \\
Pasture/hay (may be used for grazing or seed/hay crops) & $298,590.1$ & 30.93 \\
Row crops (corn, soybeans, sunflowers, etc.) & $443,682.7$ & 45.96 \\
Small grains (wheat, barley, oats, etc.) & $34,054.3$ & 3.53 \\
Urban/recreational grasses (parks, lawns, golf courses, air strips, etc.) & 138.5 & 0.01 \\
Woody wetlands & 938.5 & 0.10 \\
Emergent herbaceous wetlands & $77,410.0$ & 8.02 \\
\hline
\end{tabular}


county. SDASS data for 2000 indicate 81,000 acres of corn, 164,400 acres of soybeans, and 73,500 acres of wheat were harvested, with lesser amounts of hay, oats, and sunflowers (South Dakota Agricultural Statistics Service, 2001). Statewide pesticide usage information shows herbicides were applied to 100 percent of corn acreage in South Dakota and insecticides were applied to 15 percent of corn acreage in 2000 . Atrazine was the most common herbicide applied, used on 42 percent of corn acreage, while metolachlor was used on 8 percent of corn acreage. The same report stated that in 2000 , herbicides were used on 98 percent of all bean acreage with glyphosate used on 67 percent (South Dakota Agricultural Statistics Service, 2001).

A 1987 compilation of annual use estimates of 96 herbicides for all counties in the conterminous United States was published by Battaglin and Goolsby (1994). The data are published digitally and are intended for estimating regional herbicide use and for producing maps showing relative rates of herbicide use across regions (Battaglin and Goolsby, 1994). Estimated use of 34 herbicides in Roberts County in 1987 is shown in table 9. Use estimates show that 2,4-D was applied to the greatest number of acres, while EPTC was applied at the highest rate.

Because Battaglin and Goolsby used cropping data from the 1987 Census of Agriculture, it is possible that herbicide use, crop management practices, and pesticide application methods have changed and the data may no longer accurately describe pesticide use. However, other available data sets do not give pesticide-use data on a county basis and are thus less specific in relating data to the study area. The Battaglin and Goolsby data are provided as a GIS coverage on CDROM in the /pestuse/goolsby/ directory. Even though the Battaglin and Goolsby data set was clipped to the Reservation boundary, the pesticide use and application rates are totals and average for each county, not just the portion of the county that is within the Reservation.

A survey of all crop pesticide use in 1994 was conducted for crop-reporting districts in South Dakota by the South Dakota State University Extension Service (Ruden, 1994). Tables summarizing the data are accessible from URL http://www.abs.sdstate.edu/ plantsci/ext/piap/94SDACPUS/index.htm.

The National Center for Food and Agricultural Policy has a web-based database of pesticide use accessible at URL http://pestdata.ncsu.edu/ncfap/ search.cfm. The database was constructed using available published reports of pesticide use and a survey of Extension Service specialists; thus, this database may overlap other data sources presented in this report.
Table 9. Estimated use of 34 herbicides in Roberts County, South Dakota, in 1987

[Data from Battaglin and Goolsby, 1994]

\begin{tabular}{|c|c|c|c|}
\hline Pesticide & $\begin{array}{l}\text { Acres } \\
\text { treated }\end{array}$ & $\begin{array}{l}\text { Pounds of } \\
\text { active } \\
\text { ingredient } \\
\text { applied }\end{array}$ & $\begin{array}{c}\text { Pounds } \\
\text { used per } \\
\text { square mile }\end{array}$ \\
\hline Acifluorfen & 2,645 & 661 & 0.588 \\
\hline Alachlor & 30,766 & 56,397 & 50.204 \\
\hline Atrazine & 11,054 & 10,060 & 8.955 \\
\hline Bentazon & 9,523 & 7,999 & 7.121 \\
\hline Butylate & 1,299 & 5,196 & 4.625 \\
\hline Chloramben & 1,444 & 3,417 & 3.042 \\
\hline Chlorosulfuron & 4,356 & 86 & .077 \\
\hline Cyanazine & 5,845 & 6,956 & 6.192 \\
\hline $2,4-\mathrm{D}$ & 67,614 & 25,029 & 22.280 \\
\hline $2,4-\mathrm{DB}$ & 2 & 2 & .002 \\
\hline Dalapon & 48 & 36 & .032 \\
\hline Diallate & 48 & 72 & .064 \\
\hline Dicamba & 38,501 & 9,339 & 8.313 \\
\hline Diclofop & 5,261 & 3,946 & 3.513 \\
\hline Difenzoquat & 1,443 & 1,082 & .963 \\
\hline Diquat & 1 & 0 & 0 \\
\hline EPTC & 16,469 & 72,185 & 64.258 \\
\hline Ethylfluralin & 4,861 & 4,571 & 4.069 \\
\hline Fluazifop & 529 & 106 & .094 \\
\hline Glysophate & 9,187 & 4,957 & 4.413 \\
\hline Gromoxynil & 14,734 & 4,289 & 3.818 \\
\hline Imazethapyr & 5,290 & 265 & .236 \\
\hline Metolachlor & 13,135 & 29,929 & 26.642 \\
\hline Metribuzin & 3,403 & 1,040 & .926 \\
\hline Metsulfuron & 6,725 & 67 & .060 \\
\hline MPCA & 32,076 & 12,151 & 10.817 \\
\hline Pendimethalin & 6,015 & 7,314 & 6.511 \\
\hline Picloram & 1,984 & 992 & .883 \\
\hline Propachlor & 3,251 & 16,254 & 14.469 \\
\hline Sethoxydim & 1,058 & 212 & .189 \\
\hline Simazine & 758 & 1,137 & 1.012 \\
\hline Thiameturon & 9,493 & 190 & .169 \\
\hline Triallate & 3,847 & 3,847 & 3.425 \\
\hline Trifluralin & 46,345 & 35,538 & 31.635 \\
\hline
\end{tabular}




\section{REFERENCES}

Battaglin, W.A., and Goolsby, D.A., 1994, Spatial data in geographic information systems format on agricultural chemical use, land use, and cropping practices in the United States: U.S. Geological Survey WaterResources Investigations Report 94-4176, 87 p.

Carter, J. M., and Thompson, R.F., 1998, Selected hydrologic data through 1996 for the Lake Traverse Reservation/Roberts County water resources investigation in South Dakota: U.S. Geological Survey OpenFile Report 98-647, 243 p.

Environmental Systems Research Institute, Inc. (ESRI), 2000, ArcDoc version 8.0.2, patch 1: Redlands, Calif., ESRI.

Erickson, H.D., 1955, Artesian conditions in northeast South Dakota: South Dakota Geological Survey Report of Investigations No. 77, 39 p.

Flint, R.F., 1955, Pleistocene geology of eastern South Dakota: U.S. Geological Survey Professional Paper $262,173 \mathrm{p}$.

National Center for Food and Agricultural Polity Pesticide Use Database, 2001, accessed on July 30, 2001, at URL http://pestdata.ncsu.edu/ncfap/search.cfm
Natural Resources Conservation Service, 2000, STATSGO information sheet: U.S. Department of Agriculture, accessed on July 31,2000 , at URL

http://www.ftw.nrcs.usda.gov/statsgo.html

Ruden, Brad, 1994, South Dakota all-crop pesticide use survey: South Dakota State University Extension Pesticide Impact Assessment Program, accessed on August 1, 2001, at URL http://www.abs.sdstate.edu/ plantsci/ext/piap/94SDACPUS/index.htm

South Dakota Agricultural Statistics Service, 2001, South Dakota 2000 agricultural chemical usage: U.S. Department of Agriculture, accessed on July 30, 2001, at URL http://www.nass.usda.gov/sd/releases/agchem01.pdf

Thompson, R.F., 2000, Selected hydrologic and waterquality data, 1997 through 1999, for the Lake Traverse Reservation/Roberts County water-resources investigation in South Dakota: U.S. Geological Survey OpenFile Report 00-445, 304 p.

2001, Water resources of the Lake Traverse Reservation, South and North Dakota, and Roberts County, South Dakota: U.S. Geological Survey WaterResources Investigations Report 01-4219, 105 p. 
SUPPLEMENTAL INFORMATION 



\section{Disk 1}

A_document (contains metadata for coverages on Disk 1)

A_notice.txt

dem

dem_grid

info

landuse

info

landuse_grid

Disk 2

A_document (contains metadata for coverages on Disk 2)

A_notice.txt

aquifers

A_readme.doc

almn_bnd

almn_tde

bgsx_bnd

bgsx_tdep

clks_bnd

clks_tdep

dkot_top

eden_bnd

eden_tdl

frmn_bnd

frmn_tdep

hnkn_bnd

hnkn_tde

info

jmes_bnd

jmes_tde

lnlk_bnd

lnlk_tdl

mlnr_bnd

mlnr_est

mrdy_bnd

mrdy_tdl

outw_ltd

prrc_bnd

prrc_tdlp

rshl_bnd

rshl_tdep

rsln_bnd 
rsln_tdl

rvll_bnd

rvll_tdep

sprt_bnd

sprt_tdep

vbln_bnd

vbln_tdep

DRG

o46097a5.tif

o46097a5.tfw

o46097a4.tif

o46097a4.tfw

o46097a3.tif

o46097a3.tfw

o45097h4.tif

o45097h4.tfw

o45097h3.tif

045097h3.tfw

o45097h2.tif

o45097h2.tfw

o45097h1.tif

o45097h1.tfw

o45096h8.tif

o45096h8.tfw

o45096h7.tif

o45096h7.tfw

o45096h6.tif

o45096h6.tfw

o45096h5.tif

o45096h5.tfw

o45097g4.tif

o45097g4.tfw

o45097g3.tif

045097g3.tfw

o45097g2.tif

045097g2.tfw

045097g1.tif

o45097g1.tfw

045096g8.tif

o45096g8.tfw

o45096g7.tif

o45096g7.tfw

045096g6.tif

o45096g6.tfw

o45096g5.tif

o45096g5.tfw

o45097f4.tif

o45097f4.tfw 


$$
\begin{aligned}
& \text { o45097f3.tif } \\
& \text { o45097f3.tfw } \\
& \text { o45097f 2.tif } \\
& \text { o45097f2.tfw } \\
& \text { o45097f1.tif } \\
& \text { o45097fl.tfw } \\
& \text { o45096f8.tif } \\
& \text { o45096f8.tfw } \\
& \text { o45096f7.tif } \\
& \text { o45096f 7.tfw } \\
& \text { 045096f6.tif } \\
& \text { o45096f6.tfw } \\
& \text { o45097e4.tif } \\
& \text { o45097e4.tfw } \\
& \text { o45097e3.tif } \\
& \text { o45097e3.tfw } \\
& \text { o45097e2.tif } \\
& \text { o45097e2.tfw } \\
& \text { 045097el.tif } \\
& \text { o45097e1.tfw } \\
& \text { o45096e8.tif } \\
& \text { o45096e8.tfw } \\
& \text { 045096e7.tif } \\
& \text { o45096e7.tfw } \\
& \text { o45097d3.tif } \\
& \text { o45097d3.tfw } \\
& \text { o45097d2.tif } \\
& \text { o45097d2.tfw } \\
& \text { 045097d1.tif } \\
& \text { o45097d1.tfw } \\
& \text { o45096d8.tif } \\
& \text { o45096d8.tfw } \\
& \text { 045097c3.tif } \\
& \text { o45097c3.tfw } \\
& \text { o45097c2.tif } \\
& \text { o45097c2.tfw } \\
& \text { 045097cl.tif } \\
& \text { o45097c1.tfw } \\
& \text { o45096c8.tif } \\
& \text { o45096c8.tfw } \\
& \text { o45097b3.tif } \\
& \text { o45097b3.tfw } \\
& \text { o45097b2.tif } \\
& \text { o45097b2.tfw } \\
& \text { o45097bl.tif } \\
& \text { 045097b1.tfw } \\
& \text { o45097a2.tif } \\
& \text { o45097a2.tfw } \\
& \text { o45097a1.tif } \\
& \text { o45097a1.tfw }
\end{aligned}
$$


o44097h2.tif

o44097h2.tfw

pestuse

goolsby

agchem

herb 1

herb2

herb3

herb4

herb5

info

agchem 1996.htm agchem 1998.pdf agchem 1999.pdf agchem2000.pdf robco1997.htm robco 1998.htm robco $1999 . \mathrm{htm}$ robco2000.htm

soils

muir comp.xls compyld.xls elements.xls ewoodlnd.xls forest.xls hydcomp.xls inclusn.xls interp.xls layer.xls mapunit.xls mucoacre.xls muyld.xls plantcom.xls plcomname.xls plsciname.xls pwoodlnd.xls rangenm.xls rsprod.xls sdbcodes.xls ssacoac.xls ssarea.xls taxclass.xls windbrk.xls wlhabit.xls 
woodmgt.xls

yldunits.xls

ssurgo

A_SSURGO_INFO.txt

A_readme.txt

Grant

grant_a

grant_b

grant_1

grant_p

grant_q

info

Marshall

info

marshall_a

marshall_b

marshall_p

marshall_q

Roberts

info

roberts_a

roberts_b

roberts_1

roberts_p

roberts_q

Sargent

info

sargent_a

sargent_b

sargent_p

sargent_q

statsgo

statsgo_cov

watqual

ltravorganics.xls

NWIS.xls 